\title{
Analisis Gaya Kepemimpinan Kepala Sekolah Dalam Meningkatkan Kinerja Guru Di SMP Negeri 17 Kota Tangerang Selatan
}

\author{
Suprianto $^{1 *}$; Gatot Kusjono ${ }^{2}$; Novia Susanti ${ }^{3}$ \\ 1,2,3 Fakultas Ekonomi dan Bisnis, Universitas Pamulang \\ dosen00441@unpam.ac.id
}

Received 10 Agustus 2021| Revised 30 Agustus 2021 | Accepted 27 September 2021

*Korespondensi Penulis

\begin{abstract}
Abstrak
Penelitian ini bertujuan untuk Analisis Gaya Kepemimpinan Kepala Sekolah Dalam Meningkatkan Kinerja Guru Di SMP Negeri 17 Kota Tangerang Selatan. Populasi dan sampel penelitian yaitu guruguru SMPN 17 yang berjumlah sebanyak 36 responden. Metode penelitian yang digunakan deskriptif kualitatif dan kuantitatif dengan analisa data meliputi: uji instrumen (validitas dan reliabilitas), uji normalitas, regresi linier sederhana, uji koefisien determinasi, uji statistik t. Hasil penelitian diperoleh bahwa gaya kepemimpinan yang paling dominan di sekolah adalah gaya kepemimpinan demokratis. Hasil uji t diperoleh bahwa gaya kepemimpinan kepala sekolah berpengaruh terhadap kinerja guru dalam peningkatan kompetensi pedagogik, kepribadian dan professional. Dan tidak berpengaruh terhadap kinerja kompetensi sosial guru. Konstribusi gaya kepemimpinan terhadap setiap kompetensi sebesar 33,4\% terhadap kompetensi pedagogik, 36,2 \% terhadap kompetensi kepribadian, 33,4 terhadap kompetensi professional dan $13 \%$ terhadap kompetensi sosial.
\end{abstract}

Luaran yang ditargetkan dalam penelitian ini yaitu terpublikasi di jurnal ilmiah nasional ber-ISSN, serta memberikan konstribusinya terhadap ilmu pengetahuan yang dapat meningkatkan kemampuan tenaga pendidik/dosen dalam meningkatkan prestasi peserta didik/mahasiswanya.

Kata Kunci: Gaya Kepemimpinan; Kinerja Guru

\begin{abstract}
This study aims to analyze the principal's leadership style in improving teacher performance at SMP Negeri 17 Tangerang Selatan City. The population and sample of the study were the teachers of SMPN 17, which amounted to 36 respondents. The research method used is descriptive qualitative and quantitative with data analysis including: instrument test (validity and reliability), normality test, simple linear regression, coefficient of determination test, $t$ statistical test. The results showed that the most dominant leadership style in schools is the democratic leadership style. The results of the t-test showed that the principal's leadership style had an effect on teacher performance in improving pedagogic, personality and professional competencies. And it has no effect on the performance of the teacher's social competence. The contribution of leadership style to each competency is $33.4 \%$ to pedagogic competence, $36.2 \%$ to personality competence, 33.4 to professional competence and $13 \%$ to social competence.
\end{abstract}

The targeted output in this research is to be published in national scientific journals with ISSN, as well as to contribute to science that can improve the ability of educators/lecturers in improving the achievement of their students/students.

Keywords: Leadership Style; Teacher Performance 


\section{PENDAHULUAN}

Guru adalah sebuah profesi yang memerlukan kualifikasi dan kompetensi tertentu. Seperti halnya dengan Dokter dan profesi yang lain, kualifikasi dan kompetensi guru ditentukan dan diatur oleh Undang-Undang. Secara rinci dalam pasal 10 ayat 1 Undang-Undang Nomor 14 tahun 2005 tentang Guru dan Dosen mengamanatkan bahwa guru harus memiliki kompetensi pedagogik, kompetensi kepribadian, kompetensi social, dan kompetensi profesional. Keempat kompetensi tersebut bersifat holistic dan merupakan satu kesatuan yang menjadi ciri guru professional.

Professionalisme guru di atas dapat dilihat dari seberapa besar terpenuhinya kinerja guru yang dapat terlihat jelas dalam pembelajaran terhadap peserta didik. Kinerja guru yang baik akan menghasilkan prestasi belajar peserta didik yang baik. Setiap guru yang mempunyai tingkat kinerja yang tinggi akan dapat menjadikan anak didiknya berprestasi.

Permasalahan yang ada di SMP Negeri 17 Kota Tangerang Selatan adalah penilaian kinerja aparatur sipil negara (ASN) tidaklah hanya berdasar pada kinerja yang tinggi secara realita, namun pada Daftar Penilaian Pelaksanaan Penilaian (DP3) guru Pegawai Negeri Sipil. Hasil DP3 setiap tahun harus selalu naik di bandingkan dengan tahun sebelumnya akan memicu kurang maksimalnya kinerja guru. Penelitian yang dilakukan oleh Yantho dan Suprianto (2020), menunjukkan hubungan kompetensi pedagogik guru dan kinerja guru berada pada tingkat korelasi positif rendah $(0,144)$. Antara motivasi guru dan kinerja guru berada pada tingkat korelasi negatife rendah $(-0,214)$. Sedangkan secara bersama-sama antara kompetensi pedagogik guru dan motivasi guru dengan kinerja guru berada pada korelasi positif yang rendah $(0,285)$. Ini berarti kinerja guru SMP Negeri 17 Tangerang Selatan belum tercapai dengan baik.

Perubahan sosial, inovasi, teknologi dan bertambah ketatnya persaingan menghadapkan pada penerapan gaya kepemimpinan kepala sekolah pada tantangan yang sulit. Pemimpin dituntut untuk mampu merencanakan, mengkoordinasikan, dan mengorganisasikan sumber daya yang dimiliki agar berdaya guna dan berhasil untuk dapat bertahan dan berkembang di tengah lingkungan yang kompetitif. Dalam lingkungan yang demikian ketatnya kualitas sumber daya manusia sebagai aset yang utama yang merupakan tumpukan bagi kelangsungan hidup lembaga harus dapat dikelola dengan baik oleh pemimpin yang mempunyai kapasitas yang tinggi. Kapasitas kepala sekolah sebagai pemimpin harus mampu memanage Intelleqtual Capital dan mengubahnya menjadi produk dan jasa yang berguna dalam meningkatkan efektivitas kinerja guru.

Dalam hal ini peran guru tidak terlepas dari penerapan gaya kepemimpinan yang ada dalam masing-masing lembaga, akan tetapi masih banyak permasalahan yang menyebabkan menurunnya efektivitas kinerja guru yang muncul disebabkan ketidak sesuaian gaya kepemimpinan yang diterapkan, bahkan tidak jarang pada permasalahan tersebut muncul disebabkan gaya kepemimpinan yang salah karena secara tidak disadari seorang pemimpin dalam memperlakukan atau menerapkangaya kepemimpinan tersebut dalam rangka menjalankan kepemimpinannya menurut caranya sendiri dan cara-carayang digunakannya merupakan pencerminan sifat-sifat dasar kepribadian seorang pemimpin walaupun pengertian ini tidak mutlak (M. Ngalim Purwanto, 2006: 48).

Gaya kepemimpinan kepala di sekolah negeri sering pula berubah seiring dengan pelaksanaan Permendikbud Nomor 15 Tahun 2018 pasal 12 ayat 2 dan 3 berbunyi "Setiap periode jabatan kepala sekolah dilaksanakan dalam kurun waktu 4 (empat) tahun. Setelah menyelesaikan tugas pada periode pertama, Kepala Sekolah dapat diperpanjangmasa tugasnya paling banyak 3 (tiga) kali masa jabatan." Adanya pergantian kepala sekolah inilah yang memerlukan penyesuaian gaya kepemimpinan kepala sekolah dengan terhadap kebiasaan dewan guru pada sekolah yang baru dibinanya.

Berkaitan dengan hal-hal di atas, peneliti ingin mengulas jenis-jenis gaya kepemimpinan kepala sekolah untuk meningkatkan kinerja guru SMP Negeri 17 Kota Tangerang Selatan berdasarkan persepsi harapan guru dan kepala sekolah. Sehingga nantinya diperoleh persamaan persepsi menuju 
peningkatan kualitas sekolah yang diwujudkan dalam peningkatan kinerja guru. Peneliti mengambil judul penelitian "Analisis Gaya Kepemimpinan Kepala Sekolah Dalam Peningkatan Kinerja Guru di SMP Negeri 17 Kota Tangerang Selatan".

\section{Kinerja Guru}

Menurut Arif Yusuf Hamali (2016: 98) istilah "performance sering diindonesiakan sebagai performa, atau dikenal juga dengan istilah kinerja. Kinerja adalah keluaran yang dihasilkan oleh fungsifungsi atau indikator-indikator suatu pekerjaan atau suatu profesi dalam waktu tertentu. Sedangkan menurut Mangkunegara (2015: 67) dalam Sudiarto (2019: 199), kinerja merupakan hasil kerja secara kualitas dan kuantitas yang dicapai oleh seseorang karyawan dalam melaksanakan tugas sesuai dengan tanggung jawab yang diberikan kepadanya. Sedangkan menurut Malayu S.P Hasibuan (2001: 94) kinerja guru adalah "suatu hasil kerja yang dicapai seseorang guru dalam melaksanakan tugas-tugas yang dibebankan kepadanya yang didasarkan atas kecakapan, pengalaman, dan kesungguhan serta waktu. Kinerja guru dapat dilihat saat dia melaksanakan interaksi belajar-mengajar dikelas termasuk persiapannya baik dalam bentuk program semester maupun persiapan mengajar.” Kinerja guru sangat terkait dengan efektifitas guru dalam menjalankan fungsinya dan profesinya yaitu kemampuannya guru dalam proses belajar mengajar dikelas, motivasi dan disiplin kerja serta loyalitas guru terhadap pimpinan (kepala Sekolah). Dalam hal ini A. Adji Tri Budianto dan Oom Komalasari (2016: 158) dalam penelitiannya menyimpulkan bahwa pengaruh kepemimpinan kepala sekolah terhadap kinerja guru SMK PGRI 31 Legok sebesar 33,64\%.

Pengukuran indikator kinerja guru dilakukan dengan melihat penguasaan kompetensi guru yang tercantum dalam permen diknas no.16 tahun 2007 tentang kualifikasi akademik dan kompetensi guru, yaitu kompetensi pedagodik, kompetensi kepribadian, kompetensi sosal, dan kompetensi profesional.

\section{Gaya Kepemimpinan}

Menurut Robins dan Judge (2015: 410), kepemimpinan adalah kemampuan mempengaruhi suatu kelompok menuju pencapaian sebuah visi atau serangkaian tujuan. Sedangkan menurutBadeni (2013: 2), kepemimpinan didefinisikan sebagai kemampuan seseorang untuk mempengaruhisuatu kelompok ke arah tercapainya tujuan. Sedangkan menurut Tampubolon (2007: 9) gaya kepemimpinan adalah perilaku dan strategi, sebagai hasil kombinasi dari falsafah, ketrampilan, sifat, sikap, yang sering diterapkan seorang pemimpin ketika ia mencoba mempengaruhi kinerja bawahannya. Sedangkan M. Ngalim Purwanto (2006: 48-52) menyatakan bahwa gaya kepemimpinan adalah cara atau teknik seseorang dalam menjalankan suatu kepemimpinan. Terdapat beberapa macam istilah yang digunakan untuk menerangkan pendekatan umum yang dipergunakan oleh para pemimpin dalam situasi kemanusiaan antara lain: Demokratis, birokratis, neurokratis, otokratis dan laissez faire.

\section{Kerangka Berfikir Penelitian}

Kerangka berfikir penelitian ditunjukkan dalam gambar berikut.

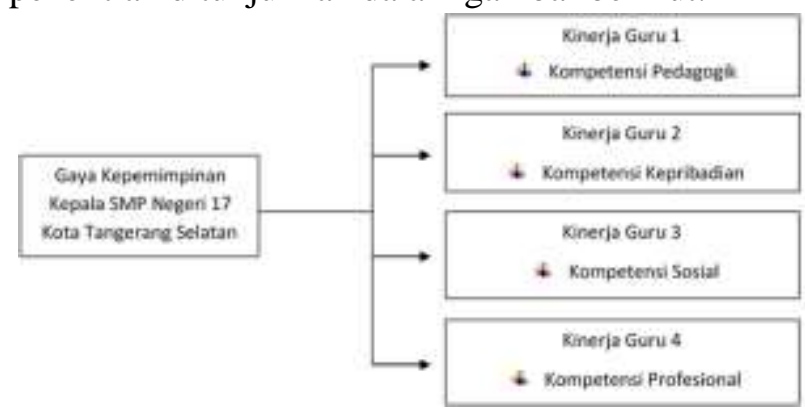

Gambar 1. Skema Kerangka Berfikir 


\section{Penelitian Terdahulu}

Penelitian yang dilakukan Denok Sunarsi (2018) dengan judul "Pengaruh Gaya Kepemimpinan, Motivasi Dan Disiplin Kerja Terhadap Kinerja Pendidik Yayasan Marvin”. Diperoleh hasil bahwa Gaya Kepemimpinan berpengaruh positif terhadap kinerja pendidik.

Penelitian yang dilakukan Septiana, R., \& Ivada, E. (2013) dengan judul "Pengaruh kepemimpinan kepala sekolah dan motivasi kerja terhadap kinerja guru SMP Negeri Wonosari". Diperoleh hasil bahwa kepemimpinan berpengaruh terhadap kinerja guru.

Penelitian yang dilakukan Guterres, L. A., \& Supartha, W. G. (2016). Berjudul "Pengaruh gaya kepemimpinan dan motivasi kerja terhadap kinerja Guru". Diperoleh hasil bahwa kepemimpinan berpengaruh terhadap kinerja guru.

Penelitian yang dilakukan A. Aji Tri Budianto dan Oom Komalasari (2016) dengan judul "Pengaruh Kepemimpinan Kepala Sekolah Terhadap Kinerja Guru Pada SMK PGRI 31 Legok". Diperoleh hasil bahwa terdapat pengaruh positif yang signifikan antara kepemimpinan terhadap kinerja guru.

\section{METODE}

Dalam penelitian ini penulis menggunakan pendekatan kuantitatif dengan jenis penilitian statistic non parametrik. Sugiyono (2007: 224) menyatakan bahwa statistic non parametrik digunakan untuk menguji hipotesis bila data penelitian berbentuk nominal atau ordinal dan tidak berdasar asumsi bahwa data harus terdistribusi normal. Peneliti menggunakan statatistik nonparametric karena data yang diolah berbentuk ordinal. Populasi merupakan wilayah generalisasi yang terdiri atas: obyek atau subyek yang mempunyai kualitas dan karakteristik tertentu yang ditetapkan oleh peneliti untuk dipelajari dan kemudian ditarik kesimpulannya. Sugiyono (2012:115). Populasi dan sampel yang akan diteliti disini adalah seluruh dewan guru di SMP Negeri 17 Kota Tangerang Selatan dengan jumlah populasi 36 orang.Adapun Analisa data yang digunakan meliputi: Analisa deskriptif, uji validitas, uji reliabilitas, uji nomalitas, regresi linier sederhana, uji koefisien korelasi, determinasi, dan uji statistik t.

\section{HASIL DAN PEMBAHASAN}

\section{Analisis Deskriptif Variabel Gaya Kepemimpinan.}

Variabel gaya kepemimpinan memiliki beberapa indikator yang dituangkan seluruhnya terhadap 17 pernyataan. Berikut analisis deskriptif kategori terhadap 17 item pernyataan pada variabel gaya kepemimpinan.

Tabel 1. Persepsi Responden Mengenai Variabel Gaya Kepemimpinan

\begin{tabular}{|c|c|c|c|c|c|c|c|c|c|}
\hline \multirow{2}{*}{ No } & \multirow{2}{*}{ Inst. } & \multicolumn{4}{|c|}{ Jawaban Responden } & \multirow{2}{*}{$\mathrm{Jml}$} & \multirow{2}{*}{ Skor } & \multirow{2}{*}{$\begin{array}{l}\text { Rata- } \\
\text { rata }\end{array}$} & \multirow{2}{*}{ Keterangan } \\
\hline & & 4 & 3 & 2 & 1 & & & & \\
\hline A & \multicolumn{9}{|c|}{ Kepemimpinan Otokrasi } \\
\hline 1 & $\mathrm{KO}-1$ & 0 & 2 & 13 & 21 & 36 & 53 & 1.47 & Kurang Sekali \\
\hline 2 & $\mathrm{KO}-2$ & 1 & 9 & 14 & 12 & 36 & 71 & 1.97 & Kurang \\
\hline 3 & $\mathrm{KO}-3$ & 0 & 0 & 9 & 27 & 36 & 45 & 1.25 & Kurang Sekali \\
\hline 4 & $\mathrm{KO}-4$ & 0 & 1 & 13 & 22 & 36 & 51 & 1.42 & Kurang Sekali \\
\hline 5 & KO-5 & 0 & 8 & 22 & 6 & 36 & 74 & 2.06 & Kurang \\
\hline \multirow[t]{2}{*}{6} & KO-6 & 0 & 1 & 9 & 26 & 36 & 47 & 1.31 & Kurang Sekali \\
\hline & Jumlah_a & 1 & 21 & 80 & 114 & 216 & 341 & 1.58 & Kurang Sekali \\
\hline $\mathrm{B}$ & \multicolumn{9}{|c|}{ Kepemimpinan Laissez Faire } \\
\hline 1 & KL-1 & 0 & 1 & 23 & 12 & 36 & 61 & 1.69 & Kurang Sekali \\
\hline 2 & KL-2 & 0 & 2 & 19 & 15 & 36 & 59 & 1.64 & Kurang Sekali \\
\hline 3 & KL-3 & 0 & 3 & 23 & 10 & 36 & 65 & 1.81 & Kurang \\
\hline 4 & KL-4 & 4 & 13 & 15 & 4 & 36 & 89 & 2.47 & Kurang \\
\hline & Jumlah_b & 4 & 19 & 80 & 41 & 144 & 274 & 1.90 & Kurang \\
\hline
\end{tabular}




\begin{tabular}{llcccccccl}
\hline \multirow{2}{*}{ No } & Inst. & \multicolumn{9}{c}{ Jawaban Responden } & \multirow{2}{*}{ Jml } & Skor & $\begin{array}{l}\text { Rata- } \\
\text { rata }\end{array}$ & Keterangan \\
\cline { 2 - 6 } $\mathrm{C}$ & Kepemimpinan Demokratis & & & & & & & \\
\hline 1 & KD-1 & 7 & 19 & 9 & 1 & 36 & 104 & 2.89 & Baik \\
\hline 2 & KD-2 & 2 & 17 & 16 & 1 & 36 & 92 & 2.56 & Baik \\
\hline 3 & KD-3 & 16 & 18 & 2 & 0 & 36 & 122 & 3.39 & Baik Sekali \\
\hline 4 & KD-4 & 24 & 10 & 2 & 0 & 36 & 130 & 3.61 & Baik Sekali \\
\hline 5 & KD-5 & 16 & 16 & 4 & 0 & 36 & 120 & 3.33 & Baik Sekali \\
\hline 6 & KD-6 & 14 & 20 & 2 & 0 & 36 & 120 & 3.33 & Baik Sekali \\
\hline 7 & KD-7 & 13 & 23 & 0 & 0 & 36 & 121 & 3.36 & Baik Sekali \\
\hline & Jumlah c & 92 & 123 & 35 & 2 & 252 & 809 & 3.21 & Baik \\
\hline
\end{tabular}

Sumber: Pengolahan data (2021)

Hasil dari persepsi 36 responden terhadap pernyataan yang berhubungan dengan gaya kepemimpinan yang dominan di lokasi penelitian. Berdasarkan hasil jawaban responden bahwa gaya kepemimpinan yang memperoleh skor tertinggi yaitu gaya kepemimpinan demokratis dengan nilai skor rata-rata 3,21 pada rentang 2,51-3,26 artinya tanggapan responden bahwa gaya kepemimpinan yang berlaku di sekolah adalah gaya kepemimpinan demokratis.

Hasil Analisa ini akan dijadikan sebagai acuan untuk mengetahui pengaruhnya terhadap kinerja guru dalam peningkatan kompetensi pedagogik, professional, kepribadian dan sosial.

\section{Deskriptif Variabel Kinerja Guru.}

Variabel kinerja guru memiliki empat kompetensi guru yaitu: yang beberapa indikator yang dituangkan seluruhnya terhadap 12 pernyataan. Berikut analisis deskriptif kategori terhadap 12 item pernyataan pada variabel gaya mengajar.

Tabel 2. Persepsi Responden Mengenai Variabel Kinerja Guru

\begin{tabular}{|c|c|c|c|c|c|c|c|c|c|}
\hline \multirow{2}{*}{ No } & \multirow{2}{*}{ Inst. } & \multicolumn{4}{|c|}{ Jawaban Responden } & \multirow{2}{*}{ Jml } & \multirow{2}{*}{ Skor } & \multirow{2}{*}{$\begin{array}{l}\text { Rata- } \\
\text { rata }\end{array}$} & \multirow{2}{*}{ Keterangan } \\
\hline & & 4 & 3 & 2 & 1 & & & & \\
\hline A & \multicolumn{9}{|c|}{ Kompetensi Pedagogik } \\
\hline 1 & KPe-1 & 15 & 21 & 0 & 0 & 36 & 123 & 3.42 & Baik Sekali \\
\hline 2 & KPe-2 & 15 & 21 & 0 & 0 & 36 & 123 & 3.42 & Baik Sekali \\
\hline 3 & KPe-3 & 9 & 21 & 6 & 0 & 36 & 111 & 3.08 & Baik \\
\hline 4 & KPe-4 & 14 & 21 & 1 & 0 & 36 & 121 & 3.36 & Baik Sekali \\
\hline 5 & KPe-5 & 12 & 21 & 3 & 0 & 36 & 117 & 3.25 & Baik \\
\hline 6 & KPe-6 & 18 & 17 & 1 & 0 & 36 & 125 & 3.47 & Baik Sekali \\
\hline 7 & KPe-7 & 10 & 25 & 1 & 0 & 36 & 117 & 3.25 & Baik \\
\hline 8 & KPe-8 & 16 & 19 & 1 & 0 & 36 & 123 & 3.42 & Baik Sekali \\
\hline 9 & KPe-9 & 13 & 23 & 0 & 0 & 36 & 121 & 3.36 & Baik Sekali \\
\hline 10 & KPe-10 & 12 & 22 & 2 & 0 & 36 & 118 & 3.28 & Baik Sekali \\
\hline 11 & KPe-11 & 11 & 21 & 4 & 0 & 36 & 115 & 3.19 & Baik \\
\hline \multirow[t]{2}{*}{12} & KPe-12 & 23 & 13 & 0 & 0 & 36 & 131 & 3.64 & Baik Sekali \\
\hline & Jumlah_a & 168 & 245 & 19 & 0 & 432 & 1445 & 3.34 & Baik Sekali \\
\hline $\mathrm{B}$ & \multicolumn{9}{|c|}{ Kompetensi Kepribadian } \\
\hline 1 & KKe-1 & 20 & 16 & 0 & 0 & 36 & 128 & 3.56 & Baik Sekali \\
\hline 2 & KKe-2 & 17 & 19 & 0 & 0 & 36 & 125 & 3.47 & Baik Sekali \\
\hline 3 & $\mathrm{KKe}-3$ & 13 & 21 & 2 & 0 & 36 & 119 & 3.31 & Baik Sekali \\
\hline 4 & $\mathrm{KKe}-4$ & 19 & 16 & 1 & 0 & 36 & 126 & 3.50 & Baik Sekali \\
\hline 5 & $\mathrm{KKe}-5$ & 23 & 13 & 0 & 0 & 36 & 131 & 3.64 & Baik Sekali \\
\hline 6 & KKe-6 & 16 & 17 & 3 & 0 & 36 & 121 & 3.36 & Baik Sekali \\
\hline \multirow[t]{2}{*}{7} & KKe-7 & 14 & 21 & 1 & 0 & 36 & 121 & 3.36 & Baik Sekali \\
\hline & Jumlah_b & 122 & 123 & 7 & 0 & 252 & 871 & 3.46 & Baik Sekali \\
\hline $\mathrm{C}$ & \multicolumn{9}{|c|}{ Kompetensi Profesional } \\
\hline 1 & KPr-1 & 17 & 19 & 0 & 0 & 36 & 125 & 3.47 & Baik Sekali \\
\hline
\end{tabular}




\begin{tabular}{|c|c|c|c|c|c|c|c|c|c|}
\hline \multirow{2}{*}{ No } & \multirow{2}{*}{ Inst. } & \multicolumn{4}{|c|}{ Jawaban Responden } & \multirow{2}{*}{$\mathrm{Jml}$} & \multirow{2}{*}{ Skor } & \multirow{2}{*}{$\begin{array}{c}\text { Rata- } \\
\text { rata }\end{array}$} & \multirow{2}{*}{ Keterangan } \\
\hline & & 4 & 3 & 2 & 1 & & & & \\
\hline 2 & KPr-2 & 16 & 20 & 0 & 0 & 36 & 124 & 3.44 & Baik Sekali \\
\hline 3 & KPr-3 & 17 & 17 & 2 & $\mathbf{0}$ & 36 & 123 & 3.42 & Baik Sekali \\
\hline 4 & KPr-4 & 13 & 23 & $\mathbf{0}$ & $\mathbf{0}$ & 36 & 121 & 3.36 & Baik Sekali \\
\hline 5 & KPr-5 & 13 & 20 & 3 & 0 & 36 & 118 & 3.28 & Baik Sekali \\
\hline 6 & KPr-6 & 11 & 23 & 2 & 0 & 36 & 117 & 3.25 & Baik \\
\hline 7 & KPr-7 & 12 & 19 & 5 & 0 & 36 & 115 & 3.19 & Baik \\
\hline \multirow[t]{2}{*}{8} & KPr-8 & 12 & 23 & 1 & 0 & 36 & 119 & 3.31 & Baik Sekali \\
\hline & Jumlah_c & 111 & 164 & 13 & 0 & 288 & 962 & 3.34 & Baik Sekali \\
\hline $\mathrm{D}$ & \multicolumn{9}{|c|}{ Kompetensi Sosial } \\
\hline 1 & KSo-1 & 12 & 22 & 2 & 0 & 36 & 118 & 3.28 & Baik Sekali \\
\hline 2 & KSo-2 & 11 & 23 & 2 & 0 & 36 & 117 & 3.25 & Baik \\
\hline 3 & KSo-3 & 13 & 22 & 1 & 0 & 36 & 120 & 3.33 & Baik Sekali \\
\hline 4 & KSo-4 & 15 & 21 & 0 & 0 & 36 & 123 & 3.42 & Baik Sekali \\
\hline \multirow[t]{3}{*}{5} & KSo-5 & 13 & 20 & 0 & 3 & 36 & 115 & 3.19 & Baik \\
\hline & Jumlah_d & 64 & 108 & 5 & 3 & 180 & 593 & 3.29 & Baik Sekali \\
\hline & Total & 465 & 640 & 44 & 3 & 1152 & 3871 & 3.36 & Baik Sekali \\
\hline
\end{tabular}

Sumber: Pengolahan data (2021)

Dari tabel di atas merupakan hasil dari persepsi 36 responden terhadap 31 item pernyataan pada variabel kinerja guru dalam empat kompetensi pendidik, diperoleh hasil dari tertinggi sampai terendah sebagai berikut:

1. Kinerja guru dalam peningkatan kompetensi kepribadian dengan skor rata-rata 3,46 pada rentang 3,26-4,00 artinya tanggapan responden terhadap kinerja guru dalam peningkatan kompetensi kepribadian adalah sangat baik.

2. Kinerja guru dalam peningkatan kompetensi pedagogik dan professional memperoleh skor rata-rata 3,34 pada rentang 3,26-4,00 artinya tanggapan responden terhadap kinerja guru dalam peningkatan kompetensi pedagogik dan professional adalah sangat baik.

3. Kinerja guru dalam peningkatan kompetensi sosial memperoleh skor rata-rata 3,29 pada pada rentang 3,26-4,00 artinya tanggapan responden terhadap kinerja guru dalam peningkatan kompetensi sosial adalah sangat baik.

Jawaban keseluruhan responden, rata-rata jawaban responden tentang variabel kinerja guru dalam peningkatan kompetensi pedagogik, professional, kepribadian dan sosial memperoleh skor rata-rata 3,36 di rentang 3,26-4,00. Hal ini menunjukkan respon responden terhadap pernyataan yang diajukan untuk variabel kinerja guru secara keseluruhan lebih memilih jawaban sangat baik. Adapun kinerja guru yang tertinggi adalah dalam bidang kompetensi kepribadian dengan rata-rata nilai skor jawaban responden 3,46 artinya kompetensi kepribadian di sekolah lebih diutamakan dibandingkan kompentensi yang lain..

\section{Uji Validitas Instrumen}

Uji validitas digunakan untuk mengukur valid atau tidaknya suatu instrumen (Husein Umar: 2009). Suatu kuesioner dikatakan valid apabila pertanyaan/butir mampu mengungkapkan sesuatu yang akan diukur oleh kuesioner tersebut. Instrumen dikatakan valid apabila hasil uji korelasi Pearson`s Product Moment diperoleh $\mathrm{r}_{\text {hitung }}$ lebih besar daripada $\mathrm{r}_{\text {tabel }}\left(\mathrm{r}_{\mathrm{h}}>\mathrm{r}_{\mathrm{t}}\right)$, dan dikatakan tidak valid jika $\mathrm{r}_{\text {hitung }}$ lebih kecil daripada $\mathrm{r}_{\text {tabel }}\left(\mathrm{r}_{\mathrm{h}}<\mathrm{r}_{\mathrm{t}}\right)$.

Tabel 3. Hasil Uji Validitas Instrumen Variabel Penelitian

\begin{tabular}{ccccc}
\hline No & Instrumen Variabel & $\mathrm{r}_{\text {hitung }}$ & $\mathrm{r}_{\text {tabel }}$ & Validitas \\
\hline $\mathbf{A}$ & Variabel Gaya Kepemimpinan $(\mathbf{X})$ & & \\
\hline 1 & Gaya-1 & $.673^{* *}$ & 0,329 & Valid \\
\hline 2 & Gaya-2 & $.460^{* *}$ & 0,329 & Valid \\
\hline 3 & Gaya-3 & $.761^{* *}$ & 0,329 & Valid \\
\hline
\end{tabular}




\begin{tabular}{|c|c|c|c|c|}
\hline No & Instrumen Variabel & $\mathrm{r}_{\text {hitung }}$ & $\mathrm{r}_{\text {tabel }}$ & Validitas \\
\hline 4 & Gaya-4 & $.660^{* *}$ & 0,329 & Valid \\
\hline 5 & Gaya-5 & $.642^{* *}$ & 0,329 & Valid \\
\hline 6 & Gaya-6 & $.652^{* *}$ & 0,329 & Valid \\
\hline 7 & Gaya-7 & $.514^{* *}$ & 0,329 & Valid \\
\hline B & \multicolumn{4}{|c|}{ Variabel Kompetensi Pedagogik $\left(\mathbf{Y}_{1}\right)$} \\
\hline 1 & K_Pedagogik1 & $.726^{* *}$ & 0,329 & Valid \\
\hline 2 & K_Pedagogik2 & $.615^{* *}$ & 0,329 & Valid \\
\hline 3 & K_Pedagogik3 & $.347^{*}$ & 0,329 & Valid \\
\hline 4 & K_Pedagogik4 & $.740^{* *}$ & 0,329 & Valid \\
\hline 5 & K_Pedagogik5 & $.753^{* *}$ & 0,329 & Valid \\
\hline 6 & K_Pedagogik6 & $.711^{* *}$ & 0,329 & Valid \\
\hline 7 & K_Pedagogik7 & $.761^{* *}$ & 0,329 & Valid \\
\hline 8 & K_Pedagogik8 & $.766^{* *}$ & 0,329 & Valid \\
\hline 9 & K_Pedagogik9 & $.774^{* *}$ & 0,329 & Valid \\
\hline 10 & K_Pedagogik10 & $.768^{* *}$ & 0,329 & Valid \\
\hline 11 & K_Pedagogik11 & $.800^{* *}$ & 0,329 & Valid \\
\hline 12 & K_Pedagogik12 & $.757^{* *}$ & 0,329 & Valid \\
\hline $\mathbf{C}$ & \multicolumn{4}{|c|}{ Variabel Kompetensi Kepribadian ( $\left.\mathrm{Y}_{2}\right)$} \\
\hline 1 & K_Pribadi1 & $.811^{* *}$ & 0,329 & Valid \\
\hline 2 & K_Pribadi2 & $.818^{* *}$ & 0,329 & Valid \\
\hline 3 & K_Pribadi3 & $.754^{* *}$ & 0,329 & Valid \\
\hline 4 & K_Pribadi4 & $.719^{* *}$ & 0,329 & Valid \\
\hline 5 & K_Pribadi5 & $.809^{* *}$ & 0,329 & Valid \\
\hline 6 & K_Pribadi6 & $.853^{* *}$ & 0,329 & Valid \\
\hline 7 & K_Pribadi7 & $.760^{* *}$ & 0,329 & Valid \\
\hline D & \multicolumn{4}{|c|}{ Variabel Kompetensi Profesional $\left(\mathrm{Y}_{3}\right)$} \\
\hline 1 & K_Proff1 & $.704^{* *}$ & 0,329 & Valid \\
\hline 2 & K_Proff2 & $.893^{* *}$ & 0,329 & Valid \\
\hline 3 & K_Proff3 & $.808^{* *}$ & 0,329 & Valid \\
\hline 4 & K_Proff4 & $.812^{* *}$ & 0,329 & Valid \\
\hline 5 & K_Proff5 & $.815^{* *}$ & 0,329 & Valid \\
\hline 6 & K_Proff6 & $.799^{* *}$ & 0,329 & Valid \\
\hline 7 & K_Proff7 & $.811^{* *}$ & 0,329 & Valid \\
\hline 8 & K_Proff8 & $.776^{* *}$ & 0,329 & Valid \\
\hline $\mathbf{E}$ & \multicolumn{4}{|c|}{ Variabel Kompetensi Sosial $\left(\mathrm{Y}_{4}\right)$} \\
\hline 1 & K_Sos1 & $.796^{* *}$ & 0,329 & Valid \\
\hline 2 & K_Sos 2 & $.824^{* *}$ & 0,329 & Valid \\
\hline 3 & K_Sos3 & $.798^{* *}$ & 0,329 & Valid \\
\hline 4 & K_Sos4 & $.843^{* *}$ & 0,329 & Valid \\
\hline 5 & K_Sos5 & $.661^{* *}$ & 0,329 & Valid \\
\hline
\end{tabular}

Sumber: Hasil Olah Data SPSS (2021)

Hasil Uji Validitas instrumen, diperoleh hasil bahwa semua butir pernyataan dinyatakan valid karena semua item-item pernyataan memiliki nilai $r_{\text {hitung }}$ lebih besar dari nilai $r_{\text {tabel }}(0,329)$. 


\section{Uji Reliabilitas}

Uji reliabilitas berguna "untuk menetapkan apakah instrumen dalam hal ini kuesioner dapat digunakan lebih dari satu kali. Reliabilitas merupakah salah satu ciri atau karakter utama instrumen pengukuran yang baik" (Husein Umar: 2008). "Suatu konstruks dikatakan reliabel apabila memberikan nilai AlphaCronbach $>0.60$. Kategori koefisien reliabilitas" (Hair, 2018: 145) sebagai berikut:

Tabel 4. Hasil Uji Reliabilitas

\begin{tabular}{lcl}
\hline \multicolumn{1}{c}{ Variabel } & Cronbach's Alpha & Simpulan \\
\hline Gaya Kepemimpinan $(\mathrm{X})$ & 0.735 & Reliabel \\
\hline Kompetensi Pedagogik $\left(\mathrm{Y}_{1}\right)$ & 0.906 & Reliabel \\
\hline Kompetensi Kepribadian $\left(\mathrm{Y}_{2}\right)$ & 0.897 & Reliabel \\
\hline Kompetensi Profesional $\left(\mathrm{Y}_{3}\right)$ & 0.919 & Reliabel \\
\hline Kompetensi Sosial $\left(\mathrm{Y}_{4}\right)$ & 0.815 & Reliabel \\
\hline
\end{tabular}

Hasil pengujian reliabilitas variabel gaya kepemimpinan $(\mathrm{X})$, kompetensi pedagogik $\left(\mathrm{Y}_{1}\right)$, kompetensi kepribadian $\left(\mathrm{Y}_{2}\right)$, kompetensi professional $\left(\mathrm{Y}_{3}\right)$, dan kompetensi sosisal $\left(\mathrm{Y}_{4}\right)$ diperoleh nilai Cronbach's Alpha lebih besar dari 0,60. Artinya seluruh instrumen penelitian reliabel digunakan untuk mengumpulkan data penelitian.

\section{Uji Normalitas}

Pengujian normalitas menggunakan nilai Asymp.Sig. (2-tailed) dengan kriteria apabila sig. (2 tailed) $>0.05$, dinyatakan bahwa data berasal dari populasi yang berdistribusi normal (Sudarmanto, 2015).

Tabel 5. Hasil Uji Normalitas

\begin{tabular}{llrrrrr} 
& & \multicolumn{2}{c}{ Abs_Res } & Abs_Res & Abs_Res & \multicolumn{2}{c}{ Abs_Res } \\
& & XY1 & XY2 & XY3 & XY4 \\
\hline $\mathrm{N}$ & & 17 & 17 & 17 & 17 \\
\hline \multirow{2}{*}{$\begin{array}{l}\text { Normal } \\
\text { Parameters }\end{array}$} & Mean & Std. Deviation & 3.799848 & 2.21893 & 3.799848 & 2.105957 \\
\cline { 2 - 7 } & Absolute & 0.15 & 0.176 & 0.15 & 0.246 \\
\cline { 2 - 7 } $\begin{array}{l}\text { Most Extreme } \\
\text { Differences }\end{array}$ & Positive & 0.15 & 0.176 & 0.15 & 0.246 \\
\cline { 2 - 7 } & Negative & -0.149 & -0.108 & -0.149 & -0.133 \\
\hline Kolmogorov-Smirnov Z & 0.619 & 0.726 & 0.619 & 1.016 \\
\hline Asymp. Sig. (2-tailed) & 0.838 & 0.668 & 0.838 & 0.253 \\
\hline
\end{tabular}

a. Test distribution is Normal.

b. Calculated from data.

Sumber : hasil olahan SPSS, 2021

Dari hasil pengujian diperoleh angka signifikan keseluruhan residu lebih besar dari $0.05(>5 \%)$, dengan demikian sebaran data residual berdistribusi normal. Sehingga bisa dikatakan dalam hal ini datadata tersebut baik untuk dianalisis lebih lanjut karena data berasal dari populasi yang berdistribusi secara normal.

\section{Analisis Regresi Linier Sederhana}


Analisis regresi linier sederhana digunakan untuk mengukur besarnya pengaruh variabel terikat dan memprediksi variabel terikat dengan menggunakan variabel bebas

\section{Pengaruh Gaya Kepemimpinan $(X)$ terhadap Kinerja Kompetensi Pedagogik Guru $\left(Y_{1}\right)$.}

Hasil analisa pengaruh variabel gaya kepemimpinan terhadap kompetensi pedagogik guru seperti ditunjukkan pada tabel berikut.

Tabel 6. Regresi Linier Sederhana Pengaruh Variabel Gaya Kepemimpinan (X) terhadap Kinerja Kompetensi Pedagogik Guru

\begin{tabular}{lrrc}
\hline Variabel & Koefisien & t $_{\text {hitung }}$ & Sig. \\
\hline Konstanta & 17,160 & 2,119 & 0,051 \\
\hline Gaya Kepemimpinan & 0,982 & 2,745 & 0,015 \\
\hline $\mathrm{R}$ & 0,578 & & \\
$\mathrm{R}^{2}$ & 0,334 & & \\
\hline
\end{tabular}

Sumber: Pengolahan data (2021)

Berdasarkan tabel di atas diperoleh persamaan regresi linier sederhana $Y_{1}=17,160+0,982 X$. Angka konstanta 17,160 menyatakan apabila tidak ada pengaruh dari variabel gaya kepemimpinan, maka kompetensi pedagogik guru sudah mempunyai nilai sebesar 17,160. Sedangkan angka koefisien regresi 0,982 menjelaskan bahwa setiap penambahan satu nilai variabel gaya kepemimpinan akan meningkatkan kompetensi pedagogik guru sebesar 0,982 kali. Adapun besarnya konstribusi yang diberikan gaya kepemimpinan terhadap kompetensi pedagogik guru guru sebesar $33,4 \%$. Hasil uji t diperoleh nilai $t_{\text {tabel }}(2,745)>t_{\text {hitung }}(2,0322)$ dengan nilai signifikansi $0,015<0,05$, sehingga Ho ditolak dan $\mathrm{H}_{1}$ diterima. Artinya Gaya Kepemimpinan berpengaruh signifikan terhadap kompetensi pedagogik guru.

\section{Pengaruh Gaya Kepemimpinan (X) terhadap Kinerja Kompetensi Kepribadian Guru $\left(\mathbf{Y}_{2}\right)$.}

Hasil analisa pengaruh variabel gaya kepemimpinan terhadap kinerja kompetensi kepribadian guru seperti ditunjukkan pada tabel berikut.

Tabel 7. Regresi Linier Sederhana Pengaruh Variabel Gaya Kepemimpinan (X) terhadap Kinerja Kompetensi Kepribadian Guru

\begin{tabular}{lccc}
\hline Variabel & Koefisien & $\mathrm{t}_{\text {hitung }}$ & Sig. \\
\hline Konstanta & 44,751 & 2,114 & 0,052 \\
\hline Gaya Kepemimpinan & 0,610 & 2,919 & 0,011 \\
\hline $\mathrm{R}$ & 0,602 & & \\
$\mathrm{R}^{2}$ & 0,362 & & \\
\hline
\end{tabular}

Sumber: Pengolahan data (2021)

Berdasarkan tabel di atas diperoleh persamaan regresi linier sederhana $Y_{2}=44,751+0,610 X$ Angka konstanta 44,751 menyatakan apabila tidak ada pengaruh dari variabel gaya kepemimpinan, maka kompetensi kepribadian guru sudah mempunyai nilai sebesar 44,751. Sedangkan angka koefisien regresi 0,610 menjelaskan bahwa setiap penambahan satu nilai variabel gaya kepemimpinan akan meningkatkan kompetensi kepribadian guru sebesar 0,610 kali. Adapun besarnya konstribusi yang diberikan gaya kepemimpinan terhadap kompetensi kepribadian guru guru sebesar $36,2 \%$. Hasil uji $t$ diperoleh nilai $t_{\text {tabel }}(2,919)>t_{\text {hitung }}(2,0322)$ dengan nilai signifikansi $0,011<0,05$, sehingga Ho ditolak dan $\mathrm{H}_{1}$ diterima. Artinya Gaya Kepemimpinan berpengaruh signifikan terhadap kompetensi kepribadian guru.

\section{Pengaruh Gaya Kepemimpinan (X) terhadap Kinerja Kompetensi Profesional Guru ( $\left.\mathbf{Y}_{3}\right)$.}

Hasil analisa pengaruh variabel gaya kepemimpinan terhadap kinerja kompetensi profesional guru seperti ditunjukkan pada tabel berikut.

Tabel 8. Regresi Linier Sederhana Pengaruh Variabel Gaya Kepemimpinan (X) 
terhadap Kinerja Kompetensi Profesional Guru

\begin{tabular}{lrrr}
\hline Variabel & Koefisien & $\mathrm{t}_{\text {hitung }}$ & Sig. \\
\hline Konstanta & 17,160 & 2,119 & 0,051 \\
\hline Gaya Kepemimpinan & 0,982 & 2,745 & 0,015 \\
\hline $\mathrm{R}$ & 0,578 & & \\
$\mathrm{R}^{2}$ & 0,334 & & \\
\hline
\end{tabular}

Sumber: Pengolahan data (2021)

Berdasarkan tabel di atas diperoleh persamaan regresi linier sederhana $Y_{3}=17,160+0,982 X$ Angka konstanta 17,160 menyatakan apabila tidak ada pengaruh dari variabel gaya kepemimpinan, maka kompetensi profesional guru sudah mempunyai nilai sebesar 17,160. Sedangkan angka koefisien regresi 0,982 menjelaskan bahwa setiap penambahan satu nilai variabel gaya kepemimpinan akan meningkatkan kompetensi profesional guru sebesar 0,982 kali. Adapun besarnya konstribusi yang diberikan gaya kepemimpinan terhadap kompetensi profesional guru guru sebesar $33,4 \%$. Hasil uji $t$ diperoleh nilai $t_{\text {tabel }}(2,745)>t_{\text {hitung }}(2,0322)$ dengan nilai signifikansi $0,015<0,05$, sehingga Ho ditolak dan $\mathrm{H}_{1}$ diterima. Artinya Gaya Kepemimpinan berpengaruh signifikan terhadap kompetensi profesional guru.

\section{Pengaruh Gaya Kepemimpinan (X) terhadap Kinerja Kompetensi Sosial Guru ( $\left.\mathbf{Y}_{4}\right)$.}

Hasil analisa pengaruh variabel gaya kepemimpinan terhadap kinerja kompetensi sosial guru seperti ditunjukkan pada tabel berikut.

Tabel 9. Regresi Linier Sederhana Pengaruh Variabel Gaya Kepemimpinan (X) terhadap Kinerja Kompetensi Sosial Guru

\begin{tabular}{lccc}
\hline Variabel & Koefisien & thitung & Sig. \\
\hline Konstanta & 9,632 & 2,146 & 0,049 \\
\hline Gaya Kepemimpinan & 0,229 & 1,495 & 0,156 \\
\hline $\mathrm{R}$ & 0,360 & & \\
$\mathrm{R}^{2}$ & 0,130 & & \\
\hline
\end{tabular}

Sumber: Pengolahan data (2021)

Berdasarkan tabel di atas diperoleh persamaan regresi linier sederhana $\mathrm{Y}_{4}=9,632+0,229 \mathrm{X}$. Angka konstanta 9,632 menyatakan apabila tidak ada pengaruh dari variabel gaya kepemimpinan, maka kompetensi sosial guru sudah mempunyai nilai sebesar 9,632. Sedangkan angka koefisien regresi 0,229 menjelaskan bahwa setiap penambahan satu nilai variabel gaya kepemimpinan akan meningkatkan kompetensi sosial guru sebesar 0,229 kali. Adapun besarnya konstribusi yang diberikan gaya kepemimpinan terhadap kompetensi profesional guru guru sebesar $13 \%$. Hasil uji t diperoleh nilai $t_{\text {tabel }}(1,495)<t_{\text {hitung }}(2,0322)$ dengan nilai signifikansi $0,156>0,05$, sehingga Ho diterima dan $\mathrm{H}_{1}$ ditolak. Artinya Gaya Kepemimpinan tidak berpengaruh signifikan terhadap kompetensi sosial guru.

\section{Pembahasan}

\section{Gaya Kepemimpinan yang dominan di Sekolah.}

Hasil analisa deskriptif gaya kepemimpinan yang dominan di sekolah yaitu gaya kepemimpinan demokratis dengan nilai skor rata-rata 3,21 pada rentang 2,51-3,26 artinya tanggapan responden bahwa gaya kepemimpinan yang berlaku di sekolah adalah gaya kepemimpinan demokratis.

\section{Pengaruh Gaya Kepemimpinan (X) terhadap Kinerja Kompetensi Pedagogik Guru $\left(\mathrm{Y}_{1}\right)$.}

Hasil uji t diperoleh bahwa gaya kepemimpinan berpengaruh signifikan terhadap kinerja kompetensi pedagogik guru dengan nilai $t_{\text {tabel }}(2,745)>t_{\text {hitung }}(2,0322)$ dan nilai signifikansi $0,015<0,05$. Hasil ini diperkuat dengan persamaan regresi linier sederhana $Y_{1}=17,160+0,982 X$ dan konstribusi variabel gaya kepemimpinan terhadap kinerja kompetensi pedagogik guru sebesar 33,4\%.

3. Pengaruh Gaya Kepemimpinan (X) terhadap Kinerja Kompetensi Kepribadian Guru $\left(\mathrm{Y}_{2}\right)$. 
Hasil uji t diperoleh bahwa gaya kepemimpinan berpengaruh signifikan terhadap kinerja kompetensi kepribadian guru dengan nilai $t_{\text {tabel }}(2,919)>t_{\text {hitung }}(2,0322)$ dengan nilai signifikansi $0,011<0,05$. Hasil ini diperkuat dengan persamaan regresi linier sederhana $Y_{2}=44,751+0,610 X$ dan konstribusi variabel gaya kepemimpinan terhadap kinerja kompetensi kepribadian guru sebesar 36,2\%.

4. Pengaruh Gaya Kepemimpinan $(X)$ terhadap Kinerja Kompetensi Profesional Guru $\left(\mathbf{Y}_{3}\right)$.

Hasil uji t diperoleh bahwa gaya kepemimpinan berpengaruh signifikan terhadap kinerja kompetensi profesional guru dengan nilai $t_{\text {tabel }}(2,745)>t_{\text {hitung }}(2,0322)$ dengan nilai signifikansi $0,015<0,05$. Hasil ini diperkuat dengan persamaan regresi linier sederhana $\mathrm{Y}_{3}=17,160+0,982 \mathrm{X}$ dan konstribusi variabel gaya kepemimpinan terhadap kinerja kompetensi profesional guru sebesar 33,4\%

5. Pengaruh Gaya Kepemimpinan $(X)$ terhadap Kinerja Kompetensi Sosial Guru $\left(\mathbf{Y}_{4}\right)$.

Hasil uji t diperoleh bahwa gaya kepemimpinan tidak berpengaruh berpengaruh signifikan terhadap kinerja kompetensi sosial guru dengan nilai $t_{\text {tabel }}(1,495)<t_{\text {hitung }}(2,0322)$ dengan nilai signifikansi $0,156>0,05$. Hasil ini diperkuat dengan persamaan regresi linier sederhana $\mathrm{Y}_{4}=9,632+0,229 \mathrm{X}$ dan konstribusi variabel gaya kepemimpinan terhadap kinerja kompetensi pedagogik guru sebesar $13 \%$.

\section{SIMPULAN}

\section{Kesimpulan}

Hasil yang diperoleh dari penelitian ini antara lain:

1. Gaya kepemimpinan yang dominan di sekolah yaitu gaya kepemimpinan demokratis dengan nilai skor rata-rata 3,21 pada rentang 2,51-3,26 artinya tanggapan responden bahwa gaya kepemimpinan yang berlaku di sekolah adalah gaya kepemimpinan demokratis.

2. Gaya kepemimpinan berpengaruh signifikan terhadap kinerja kompetensi pedagogik guru dengan nilai $t_{\text {tabel }}(2,745)>t_{\text {hitung }}(2,0322)$ dan nilai signifikansi $0,015<0,05$. Besarnya konstribusi variabel gaya kepemimpinan terhadap kinerja kompetensi pedagogik guru sebesar 33,4\%.

3. Gaya kepemimpinan berpengaruh signifikan terhadap kinerja kompetensi kepribadian guru dengan nilai $t_{\text {tabel }}(2,919)>t_{\text {hitung }}(2,0322)$ dengan nilai signifikansi $0,011<0,05$. Besarnya konstribusi variabel gaya kepemimpinan terhadap kinerja kompetensi kepribadian guru sebesar 36,2\%.

4. Gaya kepemimpinan berpengaruh signifikan terhadap kinerja kompetensi profesional guru dengan nilai $t_{\text {tabel }}(2,745)>t_{\text {hitung }}(2,0322)$ dengan nilai signifikansi $0,015<0,05$. Besarnya konstribusi variabel gaya kepemimpinan terhadap kinerja kompetensi profesional guru sebesar 33,4\%.

5. Gaya kepemimpinan tidak berpengaruh berpengaruh signifikan terhadap kinerja kompetensi sosial guru dengan nilai $t_{\text {tabel }}(1,495)<t_{\text {hitung }}(2,0322)$ dengan nilai signifikansi $0,156>0,05$.

\section{Saran}

Saran-saran yang dapat dikemukakan dalam penelitian ini, antara lain:

1. Tenaga pendidik senantiasa dapat meningkatkan kinerjanya dalam kompetensi pedagogik, kepribadian, professional dan sosial. Sehingga dapat meningkatkan kualitas pendidikan di sekolah.

2. Gaya kepemimpinan yang sudah berlangsung dengan baik, agar dipertahankan dalam membantu meningkatkan kinerja guru semakinlebih baik lagi. .

3. Diperlukan penelitian lanjutan yang dapat mengungkapkan faktor-faktor lainnya yang mempengaruhi kinerja guru dalam peningkatan kompetensi pedagogik, kepribadian, professional dan kompetensi sosial guru.

\section{DAFTAR PUSTAKA}


Arikunto, Suharsimi. 2002. Prosedur Penelitian: Suatu Pendekatan Praktek, Jakarta: Rineka Cipta. Budianto, A. Aji Tri. 2016. Pengaruh Kepemimpinan Kepala Sekolah terhadap Kinerja Guru pada SMK PGRI 31 Legok. Jurnal Ilmiah Prodi Manajemen "Kreatif” Vol 4 No.1. Hal. 135 - 159.

Darma, Agus. 2004. Managemen Supervisi, Petunjuk Praktis Bagi Para Supervisor, Jakarta; Raja Grafindo Persada.

Fattah, H. Nanang. 2004. Konsep Manajemen Berbasi sSekolah dan Dewan Sekolah. Bandung: Bani Quraisy.

Guterres, L. A., \& Supartha, W. G. 2016. Pengaruh gaya kepemimpinan dan motivasi kerja terhadap kinerja Guru. E-Jurnal Ekonomi dan Bisnis Universitas Udayana, 5 (03).

Hadi, Sutrisno, 2000. Metodologi Penelitian, Jilid 2, Yogyakarta: ANDI.

Hamali, Arif Yusuf. 2016. Pemahaman Manajemen Sumber Daya Manusia. Yogyakarta: CAPS..

Herdiansyah. 2015. Metode Penelitian Kualitatif untuk Ilmu Psikologi.Jakarta: Salemba Humanika

Isnaeni, Devi Putri. 2020. Pengaruh Kompensasi dan Motivasi Kerja Terhadap Kinerja Guru PNS SD

Negeri. Jurnal Ilmiah Kreatif Prodi Manajemen. Vol 8 No. 2, Hal 15 -28

Moleong, Lexy J. 2007. Metode Penelitian Kualitatif, Bandung: Remaja Rosda karya.

Nazir, Moh. 2000. Metode Penelitian. Jakarta: Ghalia Indonesia.

Purwanto, M.Ngalim, 2006. Administrasi dan Supervisi Pendidikan, Bandung: RemajaRosdakarya.

Ridwan dan Tita Lestari, 2001. Dasar-Dasar Statistika. Bandung: Alfabeta.

Saroni, Muhammad, 2006. Manajemen Sekolah, Jogjakarta: Ar-Ruzz.

Septiana, R., \& Ivada, E. (2013). Pengaruh kepemimpinan kepala sekolah dan motivasi kerja terhadap kinerja guru SMP Negeri Wonosari. Jupe-Jurnal Pendidikan Ekonomi, 2(1).

Silaen, Sofar dan Widiono. 2013. Metodologi Penelitian Sosial Untuk Penulisan Skripsi dan Tesis. Bogor: In Media.

Sudiarto. 2019. Pengaruh Kompetensi dan Motivasi Terhadap Kinerja Guru pada SMKN 8 Jakarta Selatan. Jurnal Ekonomi Efektif. Vol.1 No. 3. Hal. 173 - 182.

Sunarsi, D. (2018). Pengaruh Gaya Kepemimpinan, Motivasi Dan Disiplin Kerja Terhadap Kinerja Pendidik Yayasan Marvin. Inovasi, 5(1), 1-18.

Usman, Husaini dan Akbar, Purnomo Setiady. 1999. Metodologi Penelitian Sosial, Jakarta: Bumi Aksara.

Yantho \& Suprianto. 2020. Hubungan Kompetensi Pedagogik dan Motivasi Kerja dengan Kinerja Guru SMP Negeri 17 Kota Tangerang Selatan. Jurnal Investigasi: Penelitian dan Pengembangan Pendidikan. Vol. 1, No 1. Hal 6-18. 